\title{
Defensive use of a co-accused's confession and the Criminal Justice Act 2003
}

\author{
By John Hartshorne * \\ Lecturer in Law, University of Leicester
}

\begin{abstract}
The Criminal Justice Act 2003 introduces statutory provisions regulating the extent to which a defendant may adduce a co-defendant's confession in a joint trial. The relevant provisions are based upon the recommendations of the Law Commission. In this article it is argued that the Law Commission's analysis was overly narrow, and that as a consequence the emerging legislation is unsatisfactory in several significant respects, to the extent that it may even be incompatible with Article 6 of the European Convention on Human Rights. The potential for curing the highlighted deficiencies within the legislation is considered. The article also discusses the extent to which a defendant may continue to adduce a co-accused's confession as a previous inconsistent statement.
\end{abstract}

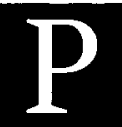

rior to the 1997 decision of the House of Lords in R v Myers, ${ }^{1}$ the extent to which a defendant in a joint trial might be permitted to adduce a confession of a co-defendant was a matter of some uncertainty. ${ }^{2}$ Whilst $R \mathrm{v}$ Myers confirmed that a defendant would not be prevented by the hearsay rule from adducing a co-accused's confession as evidence of the matters stated, the decision left unanswered questions concerning the doctrinal basis upon which the court might nevertheless exclude the confession where a defendant was seeking to rely upon it. ${ }^{3}$ The Criminal Justice Act 2003 (CJA) now places these issues on a statutory footing, and spells out the basis upon which a confession may be excluded where it is a joint defendant that has applied for the confession to be admitted, rather than

- I would like to thank Andrew Choo for his helpful comments upon an earlier draft of this article. The opinions ventured, and any legal inaccuracies, remain mine alone.

1 [1998] AC 124.

2 For discussion of this uncertainty, and the extent to which it was removed by the decision in $R$ v Myers, see M. Hirst, 'Confessions as Proof of Innocence' (1998) 57 CLJ 146, and J. Hartshorne and A. L.-T. Choo, 'Hearsay Fiddles in the House of Lords' (1999) 62 MLR 290.

3 See ibid. 
the Crown. The CJA also alters the evidential status of a previous inconsistent statement that is proved against a witness pursuant to s. 4 of the Criminal Procedure Act 1865. This latter development is a significant one for joint defendants, as prior to the CJA it was possible for a defendant to damage the credibility of a co-defendant by proving his confession against him as a previous inconsistent statement. The aforementioned provisions of the $\mathrm{CJA}^{4}$ are based upon the recommendations of the Law Commission in its report Evidence in Criminal Proceedings: Hearsay and Related Topics. ${ }^{5}$ In this article it is contended that the Law Commission's analysis of the question of whether, and if so when, a defendant may be permitted to adduce a coaccused's confession as evidence of the matters stated, was inadequate owing to the Law Commission's failure to consider what may be described as the 'confession issues' that were presented by this question, in addition to the hearsay issues. As Murphy has observed, confessions 'present problems rather different from those traditionally associated with hearsay. They were, and are, governed by rules of reliability of a different kind, dealing with the manner in which the confession is obtained. ${ }^{6}$ It is suggested that the narrow approach taken by the Law Commission has resulted in the enactment of legislation that is deficient in several significant respects. Some of these deficiencies could be cured through judicial interpretation, but ultimately it is contended that amendment will be required in order to guarantee that the provisions are fully compatible with Article 6 of the European Convention on Human Rights.

\section{The tension when a defendant applies to adduce a co-defendant's confession and the construction offered by the C.JA}

This article focuses upon the tension that is generated when a defendant applies to adduce a co-accused's confession, in circumstances where that confession has not been relied upon by the Crown, whether in consequence of exclusion of the confession or otherwise. A defendant who is anxious to establish his innocence by pointing the finger of blame at his co-accused is thereby provided with the incentive for seeking to adduce his co-accused's confession. In turn the co-accused may have several motives for seeking to have the confession excluded: he may doubt the likelihood of the jury following the judge's direction that the confession is not to be taken into account as part of the Crown's case against him; he may allege that the confession is lacking in authenticity or reliability; he may contend that it was obtained in circumstances which amounted to a breach of his protective rights; or he may simply fear that the admission of the confession might inexorably lead to the jury finding that he, and not his co-accused, is the guilty party. The merits of the joint defendants' contrasting

4 At the time of writing, the relevant sections were not yet in force.

$5 \mathrm{Cm} 3670$ (1997).

6 P. Murphy, 'Hearsay: The Road to Reform' (1997) 1 E \& P 107 at 109. 
agendas within this tension ought to be judged before any attempt is made at constructing a rule of evidence that determines whether, and if so in what circumstances, one of them may be entitled to adduce a confession of the other.

The construction that is offered by the CJA is contained in s. 128(1), which has the effect of inserting a new s. 76A into the Police and Criminal Evidence Act 1984 (PACE). For the purposes of this article, ss. 76A(1) and (2) are pertinent:

(1) In any proceedings a confession made by an accused person may be given in evidence for another person charged in the same proceedings (a coaccused) in so far as it is relevant to any matter in issue in the proceedings and is not excluded by the court in pursuance of this section.

(2) If, in any proceedings where a co-accused proposes to give in evidence a confession made by an accused person, it is represented to the court that the confession was or may have been obtained-

(a) by oppression of the person who made it; or

(b) in consequence of anything said or done which was likely, in the circumstances existing at the time, to render unreliable any confession which might be made by him in consequence thereof,

the court shall not allow the confession to be given in evidence for the co-accused except in so far as it is proved to the court on the balance of probabilities that the confession (notwithstanding that it may be true) was not so obtained.

Section 76A is almost identical to s. 76 of PACE, which regulates the extent to which the Crown may adduce an accused's confession, but there is a subtle distinction in that where the question of oppression or unreliability is raised pursuant to s. $76 \mathrm{~A}(2)$, the presumption in favour of exclusion may be rebutted by a defendant on a balance of probabilities, whereas where it is raised pursuant to s. 76(2), the presumption may only be rebutted by the Crown upon proof beyond reasonable doubt.

Section 76A apparently reflects the following conclusions of the Law Commission. First, that a defendant should have a prima facie right to adduce his co-accused's confession, where it would be relevant to his defence. Secondly, that this prima facie right should be qualified where on balance the confession appears to have been obtained by oppression, irrespective of whether the confession is true or not. Thirdly, that this prima facie right should be qualified where on balance the confession appears to have been obtained as a result of things said or done which were likely to render such a confession unreliable, irrespective of whether the actual confession is unreliable or not. In more general terms, therefore, s. 76A is apparently based upon 
the conclusions of the Law Commission that two particular interests of a co-defendant should be promoted in any resulting legislation: the vindication of serious breaches of his protective rights; and the receipt of a fair trial through the exclusion of unreliable evidence.

Somewhat surprisingly, these judgments that s. 76A appears to reflect cannot be traced back to any reasoning or recommendations to this effect within the Law Commission's report. The background to s. $76 \mathrm{~A}$ was considered in a single page of the Law Commission's report, ${ }^{7}$ and actual analysis of the issue was restricted to a single paragraph, in which the Law Commission stated:

Given that we are recommending the codification of the hearsay rule, it seems to us that the best way to ensure the harmonious development of the law on the admissibility of confessions, at the instance of the prosecution and at that of a co-accused, is to adapt the principle of section $76(2)$ to the case where one defendant seeks to adduce the confession of another. The only difference would be in the applicable standard of proof: the prosecution has to satisfy section $76(2)$ to the criminal standard of proof, but a co-accused would have to satisfy the analogous requirement only on the balance of probabilities. ${ }^{8}$

This recommendation reflected a broad theme of the Law Commission's report that in general the admissibility of hearsay evidence should not differ as between the Crown and the defence. ${ }^{9}$ The Law Commission's failure to analyse or to even identify the tension that is generated when one defendant wishes to adduce another's confession may be attributed, it is suggested, to a choice of interpretation. The Law Commission's terms of reference were 'to consider the law of England and Wales relating to hearsay evidence'. ${ }^{10}$ It is arguable that the Law Commission interpreted this brief literally, and in consequence focused its analysis almost exclusively on hearsay issues that arise when a defendant wishes to adduce a co-accused's confession, at the expense of other relevant considerations such as the function of exclusionary provisions in addressing police malpractice. Whilst the Law Commission may be forgiven for adopting this approach, it would be unfortunate if it has resulted in the enactment of legislation that is deficient in terms of its potential to promote those interests that should have priority where in a joint trial a defendant applies to adduce a co-defendant's confession. In order to evaluate the merits of s. 76A, it is

\footnotetext{
7 Above n. 5 at $118-19$.

8 Above n. 5 at para. 8.95 .

9 Above n. 5 at para. 12.8.

10 Above n. 5 at para. 1.1.
} 
therefore first necessary to address the issue that the Law Commission omitted to address: where a defendant seeks to adduce a co-defendant's confession in a joint trial, which party's agenda should take priority?

\section{The priority of interests in a joint trial}

A theme that has emerged in the law of evidence is that a defendant has an unfettered right, subject to considerations of relevance, to assert his innocence by deploying his case as he believes fit. ${ }^{11}$ An aspect of this theme has been the development of the principle that in a joint trial a judge has no discretionary common law power to exclude relevant evidence on the basis that its prejudicial effect to one accused outweighs its probative value to the other. ${ }^{12}$ The absolute right of a defendant to adduce relevant evidence can of course be qualified by the operation of an exclusionary rule; ${ }^{13}$ however, the emphasis that has been placed upon the prima facie entitlement to adduce relevant evidence suggests that an exclusionary rule should only be applied to the defence in limited circumstances, and where this is absolutely required. These developments provide strong support for the argument that in a joint trial a defendant should have an unfettered entitlement to adduce a co-defendant's confession.

This compelling claim might nevertheless have to be qualified to accommodate a co-defendant's equally compelling reasons for seeking to have the confession excluded. Reservations concerning the likelihood of the jury following the judge's warning against equating the confession with the Crown's case are not, it is suggested, sufficiently cogent reasons for qualifying a defendant's prima facie entitlement to adduce evidence of the confession; jurors must be credited with powers of being able to follow clear and strong judicial warnings. Where there is a danger that they might not do so, a preferable method of addressing this is through severing the indictment and ordering separate trials, ${ }^{14}$ rather than depriving a defendant of evidence that might make a crucial difference in terms of his conviction or acquittal. A more cogent basis for qualifying a defendant's prima facie entitlement is where the confession is unreliable. The unfettered right to adduce evidence should not extend to evidence that is either manifestly fabricated, or patently unreliable. Unfortunately confession evidence is a type of evidence that is particularly susceptible to such vices. ${ }^{15}$

11 See e.g. Murdoch v Taylor [1965] AC 574, and Lobban v R [1995] 2 Cr App R 573.

12 R v Miller [1952] 2 All ER 667, R v Neale (1977) 65 Cr App R 304, Lobban v R [1995] 2 Cr App R 573, $R$ v Randall [2004] 1 WLR 56.

13 For example, Youth Justice and Criminal Evidence Act 1999, s. 41(1).

14 See e.g. R v O'Boyle (1991) 92 Cr App R 202, and R v Clare [1995] Crim LR 726.

15 See I. Dennis, 'Miscarriages of Justice and the Law of Confessions: Evidentiary Issues and Solutions' [1993] PL 291. 
A more difficult issue is whether a defendant's prima facie entitlement to adduce a co-accused's confession ought to be qualified where the confession in question was obtained in circumstances which involved a breach of the co-defendant's protective rights, but where nevertheless the confession appears to be reliable. For example the confession might have been beaten out of the co-defendant, or obtained following a wrongful denial of access to a solicitor, but as a result of the factual information yielded by the confession it might be evident that it is truthful. Human rights considerations are particularly pertinent to this issue. If the jury's decision to convict the co-defendant might have been influenced by the admission into evidence of a confession obtained against his will, this would undoubtedly represent a breach of Article $6 .{ }^{16}$ It is suggested, however, that where it can be demonstrated that the confession might be reliable, the avoidance of a wrongful conviction should take precedence over any claim that the confession ought to be excluded to vindicate a breach of the co-defendant's protective or human rights, irrespective of the gravity of any such invasion. This should not be misinterpreted as an espousal of the view that breaches of a co-defendant's protective or human rights are irrelevant, or undeserving of redress; what is being suggested is that, once again, in a joint trial a more appropriate mechanism for offering redress, and complying with Article 6, lies in the trial judge's discretion to sever the indictment and order separate trials. ${ }^{17}$

As a result of this analysis it is contended that a defendant in a joint trial should have a prima facie right to adduce a co-defendant's confession, and that this right should only be qualified in those circumstances where the confession is so obviously lacking in reliability that it may be described as 'worthless evidence' ${ }^{18}$ Instead, as the following section will seek to illustrate, s. 76A will in some instances not only fail to vindicate a defendant's prima facie right to adduce a co-defendant's confession, but it will also offer insufficient protection to a co-defendant who is seeking to resist the admission of the confession on the basis that it is unreliable.

16 For example, in Montgomery v HM Advocate and Another [2001] 2 WLR 779, Lord Hoffmann noted obiter (at 785) that a defendant would not have received a fair trial if he had been convicted on a confession extracted from him using torture. Similarly in Austria v Italy (1963) 6 Yearbook 740, it was observed by the European Commission obiter (at 784) that if the accused had been subjected to maltreatment with the aim of extracting a confession from him, Article 6 could be regarded as being violated if the court subsequently admitted the confession into evidence. Extracting a confession against the will of a defendant would also arguably represent a breach of Article 6 on the basis that the defendant's right against selfincrimination had been infringed. The European Court of Human Rights appears to be adopting an increasingly strict approach towards the protection of this right. See e.g. Saunders v United Kingdom (1997) 23 EHRR 313, Heaney and McGuinness v Ireland (2001) 33 EHRR 12, JB v Switzerland 3 IIL Rep 663, and Allan v United Kingdom (2003) 36 EHRR 12.

17 See $R$ v Lake (1977) 64 Cr App R 172.

18 An expression that is borrowed from Lord Hope's judgment in $R v$ Myers. The concept of 'worthlessness' will be explored in more detail later on in this article. 


\section{Criticism of s. $76 \mathrm{~A}$}

For a defendant who is seeking to adduce a co-defendant's confession, the major drawback within s. 76A is that it has the potential to prevent him from adducing evidence that is both relevant and reliable. This possibility arises from the wording of s. 76A(2), which explicitly allows a confession to be excluded 'notwithstanding that it may be true'. Where it is the Crown that is seeking to rely upon the confession, there are good reasons why sometimes a confession should be excluded notwithstanding that it may be true, and it is therefore appropriate that this possibility should be provided for within s. 76(2) of PACE.$^{19}$ Following on from the conclusions that were reached in the previous section, however, it is suggested that it is wholly inappropriate that this possibility should exist within s. 76A(2). In fact it is likely that the only reason why this possibility does exist within s. 76A(2) is because the provision was modelled upon s. 76(2), following the Law Commission's recommendations, without proper consideration having first been given to the question of whether an exclusionary rule that was developed with the Crown in mind was necessarily an appropriate one to be applied to the defence. ${ }^{20}$ As Hirst has observed, 'can it ever be right to prevent defendant A from proving defendant B's confession, when there may be evidence to suggest that the confession is true?'21

From a co-defendant's perspective, s. 76A is an equally unsatisfactory provision. Similarly this may be attributed to the fact that s. 76A(2) mirrors s. 76(2). Since the enactment of s. 76(2) it has come to light that this subsection suffers from a number of limitations, but the injustices that this might have led to have in many cases been avoided through the use of s. 78(1) of PACE, or the judge's common law powers of discretionary exclusion preserved by s. 82(3) of PACE. Inevitably these same limitations will also be present within s. 76A(2), but their potential to inflict injustice upon a codefendant may not be ameliorated by the use of s. 78(1), or the judge's common law powers, owing to the fact that these latter measures do not apply to the defence. ${ }^{22}$ For example, a glaring limitation in the wording of s. 76(2), which is reproduced in $s$. $76 \mathrm{~A}(2)$, is that the subsection only applies where the Crown 'proposes to give in evidence a confession made by an accused person'. In $R$ v Sat-Bhambra ${ }^{23}$ it was held

19 See e.g. the discussion of this issue in The Criminal Law Revision Committee Eleventh Report. Evidence (General), Cmnd 4991 (1972), paras. 61-65, upon whose recommendations s. 76(2) was based.

20 Indeed the Law Commission's theme that the Crown and the defence should be bound by the same rules on hearsay was arguably anomalous, given the differences that exist in this respect in other areas of the law of evidence, e.g. that relating to evidence of the accused's bad character.

21 Above n. 2 at 162.

22 Section 78(1) makes clear reference to evidence on which the prosecution proposes to rely to be given, and it has been established that a trial judge has no inherent common law discretion to exclude relevant defence evidence (see Lobban v R [1995] 2 Cr App R 573).

23 (1989) 88 Cr App R 55. 
that this expression within s. 76(2) necessarily temporally restricts its application to a period before the confession has been given in evidence. If the admissibility of the confession is challenged after it has been given in evidence, s. 76(2) (and also it would appear s. 78(1)) cannot be used to exclude the confession. ${ }^{24}$ The injustices that this could lead to may be cured by invoking the trial judge's common law powers, to inter alia direct the jury to disregard the confession, or to discharge the jury. ${ }^{25}$ Where it is a co-defendant that is seeking to challenge a confession that has already been relied upon by a defendant, however, it might be a matter of some debate concerning whether the judge's common law powers may be invoked to cure this identical drafting anomaly within s. $76 \mathrm{~A}(2)$.

A further limitation which has emerged from the operation of s. 76(2)(b) concerns the meaning of the words 'anything said or done'. In the leading authority of $R \mathrm{v}$ Goldenberg ${ }^{26}$ Neil LJ held that the expression 'anything said or done' was limited to something said or done external to the person making the confession, which was likely to have some influence on him. It was argued in this case that the defendant was a heroin addict, and that he had requested an interview, and subsequently made a false confession, in order to secure his release from custody to feed his addiction. The Court of Appeal ruled, however, that s. 76(2)(b) could not be invoked to exclude a confession where any unreliability had been brought about by something said or done by the defendant himself. This approach was followed in R v Crampton ${ }^{27}$ where Stuart-Smith LJ observed that the wording of s. 76(2)(b) seemed to postulate some words spoken by the police or acts done by them which were likely to induce unreliable confessions. For that reason it appeared doubtful to the Court of Appeal that the mere holding of an interview, at a time when the appellant was withdrawing from the symptoms of heroin addiction, was something which was done within the meaning of s. 76(2)(b). These decisions therefore eschewed a purely reliability based approach towards the interpretation of s. 76(2)(b), possibly out of an awareness that any injustices that this might lead to could be cured using s. 78(1). If Goldenberg and Crampton should be followed in the interpretation of s. $76 \mathrm{~A}(2)(\mathrm{b})$, however, this will artificially limit the range of circumstances in which a co-defendant may challenge the admission of a confession on the grounds of unreliability. This would be troubling, given that it is now understood that a confession may be unreliable for a number of reasons, only some of which may be attributed to the behaviour of the suspect's interrogators. ${ }^{28}$

24 Oddly, this reversed the position that existed prior to PACE: see R v Watson (1980) $70 \mathrm{Cr}$ App R 273.

25 R v Sat-Bhambra (1989) 88 Cr App R 55.

26 (1988) 88 Cr App R 285.

27 (1990) 92 Cr App R 369.

28 See e.g. Dennis, above n. 15 at 301-3, and G. Gudjonsson. The Psychology of Interrogations, Confessions and Testimony (Wiley: Chichester, 1992). 
An additional reason why s. 76A is unsatisfactory from a co-defendant's perspective arises out of the inconsistent approach that judges have adopted in terms of whether to use s. 76(2) or s. 78(1) as the basis for the exclusion of a confession. Given that s. 76(2) applies exclusively to confession evidence, whereas s. 78(1) applies to any evidence upon which the Crown proposes to rely, it might be expected that in practice judges would invariably choose to use s. 76(2) as the basis upon which to exclude a confession. This is not the case, however, and instead it is customary for specific breaches of PACE, or the codes of practice, to be dealt with using s. 78(1). In particular, breaches of s. 58 of PACE concerning the right to consult a solicitor whilst in custody, ${ }^{29}$ and breaches of Code $C$ concerning the recording of interviews, ${ }^{30}$ are commonly dealt with using s. 78(1) rather than s. 76(2). The concern that this raises is that where in future a co-defendant applies to the judge for a confession to be excluded pursuant to s. $76 \mathrm{~A}(2)$, following a breach of s. 58 or the recording requirements, the judge might rule that the confession is admissible on the basis that in his mind a 's. 76 type situation' has not arisen. Given that the right to consult a solicitor in particular has been described as 'one of the most important and fundamental rights of a citizen', ${ }^{31}$ this would be indefensible. The potential for this could have been avoided by drafting s. 76A(2) using novel language, rather than modelling it upon s. 76(2).

\section{Curing the deficiencies within s. 76A}

In the short term it is suggested that interpretation offers the best hope of tackling the deficiencies within s. 76A. For example a flexible interpretation of the 'anything said or done' requirement would afford greater scope for co-defendants to challenge the admissibility of a confession on the basis that it is unreliable. The decision of the Court of Appeal in Rv Walker ${ }^{32}$ serves as an illustration of how this might be achieved. Here the Court of Appeal appeared to assume that the holding of an otherwise properly conducted interview with a suspect who, unknown to the police, was at the time suffering from a severe personality disorder could amount to the thing 'said' or 'done' for the purposes of invoking s. 76(2)(b)..$^{33}$ As an authority upon the interpretation of s. 76(2), this decision was arguably arrived at per incuriam because the court did not consider Goldenberg or Crampton during its reasoning. It might, nevertheless, be justifiable to follow this decision whilst interpreting s. 76A(2), given that it is a new provision that is directed solely at the exclusion of defence evidence.

In addition it might be feasible to interpret s. 76A in a manner that would allow a confession to be excluded notwithstanding that it had already been relied upon by a

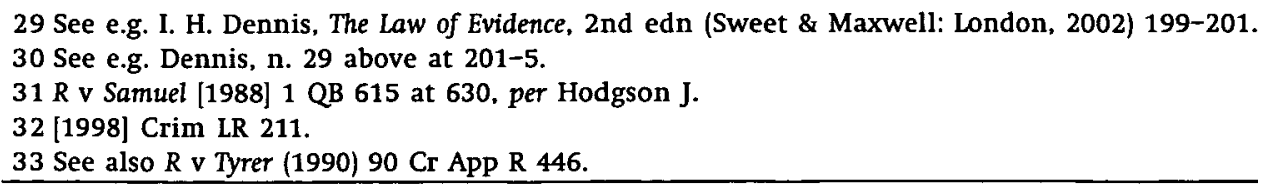


defendant. Indeed Birch, commenting on this problem in the context of s. 76(2), has stated: 'It would seem, in these enlightened times when section 3 of the Human Rights Act 1998 invites us to look afresh at matters of construction, that if the best way to achieve fairness is to hold a belated voire dire then the judge should not be shy about doing so. ${ }^{34}$ Birch raises an important issue here: rather than corrective interpretation being seen as a desirable course of action, it might instead become a mandatory one (insofar as this is achievable), if this is what is needed to guarantee that a co-defendant receives a fair trial as required by Article 6 of the European Convention on Human Rights.

For a defendant seeking to rely upon a co-defendant's confession, the wording of s. $76 \mathrm{~A}(2)$ is probably beyond corrective interpretation to the extent that it enables a confession to be excluded notwithstanding that it may be true. A confession is a dynamic item of evidence, and the exclusion of a truthful confession of a co-defendant pursuant to s. 76A(2) would in some trials have a devastating effect upon the defendant's prospects of an acquittal. The exclusion of the confession in such circumstances would undoubtedly lead to a breach of Article 6. Support for this view may be derived from the decision of the House of Lords in R vA (No. 2), ${ }^{35}$ where it was held that the prohibition imposed by s. 41(1) of the Youth Justice and Criminal Evidence Act 1999 upon the admission of consensual sexual behaviour evidence between the accused and the complainant in proceedings for rape would in some circumstances be incompatible with the accused's right to a fair trial. Whilst the House of Lords in $R v$ A (No. 2) managed to spare s. 41 from a declaration of incompatibility through a 'reading down' of the section, such a feat, it is suggested, could not imaginably be achieved in respect of s. 76A, given that any such 'interpretation' would demand expunging the expression 'notwithstanding that it may be true' from s. $76 \mathrm{~A}(2)$ altogether. Given time, therefore, s. 76A could become the subject of a declaration of incompatibility. Until this matter reaches those echelons of the criminal justice system where a declaration of incompatibility may be issued, the only option available to trial judges confronted with an Article 6 dilemma may be to sever the indictment, in order that they may then legitimately admit the confession on a discretionary basis pursuant to the 'safety valve' of s. 114(1)(d) of the CJA.

Ultimately it is contended that the deficiencies within s. 76A may only be fully cured by amendment. It is suggested that s. 76A(2) should be redrafted to make unreliability the sole basis upon which a confession may be excluded. To prevent the judge from usurping the functions of the tribunal of fact, the confession should only be excluded where the judge is satisfied that it is so unreliable that no reasonable jury could act upon it as true. A confession excluded in such circumstances could rightly be described

34 In her commentary upon the decision in R v Langley [2001] Crim LR 651. 35 [2002] 1 AC 45. 
as 'worthless'. The confession might be worthless for any number of reasons, but in order to guarantee maximum flexibility it is suggested that a redrafted s. 76A(2) should not be prescriptive in the sense of using expressions such as 'anything said or done'. Where a co-defendant does seek to challenge the admissibility of the confession on the basis of unreliability, it would be reasonable to retain the presumption in favour of exclusion, which may be rebutted by a defendant on a balance of probabilities. ${ }^{36}$ Furthermore, under a redrafted s. 76A it ought to be procedurally possible for the issue of exclusion to be considered even after the confession has been relied upon by a defendant.

This suggested formula would accord in some respects with that advanced by Lord Hope in his judgment in R v Myers. ${ }^{37}$ Lord Hope accepted that it was beyond question, as a general rule, that an accused person had the absolute right to lead all relevant evidence in his defence, but in his view this did not extend to evidence on which no reasonable jury could rely because it was 'worthless' ${ }^{38}$ One of the flaws in Lord Hope's reasoning was that he equated the circumstances that would render a confession as worthless for a defendant with those that would render it liable to exclusion for the prosecution pursuant to s. 76(2)(a) or (b). As several critics pointed out, however, a confession may be excluded pursuant to s. 76(2) notwithstanding that it might be true, and a truthful confession could hardly be described as 'worthless' from a defendant's perspective. ${ }^{39}$ That flaw does not prevent Lord Hope's concept from being utilised as the genesis for a new s. 76A, however. ${ }^{40}$

Redrafting s. 76A along the lines suggested here might attract the criticism that the threshold for exclusion had been set too high, to the prejudice of a co-defendant. It would be rash to assess the merits of the proposed s. 76A in the abstract, however. Critics should draw reassurance from the fact that where a confession was admitted pursuant to a new s. $76 \mathrm{~A}$, a co-defendant would retain the right to contest the reliability of the confession before the tribunal of fact; admission of the confession would not inexorably lead to a tribunal accepting the confession as true. ${ }^{41}$ Moreover,

36 Given the volatile nature of confession evidence.

37 [1998] AC 124.

38 Ibid. at $145-6$.

39 See e.g. Hirst, above n. 2 at 161, and the commentary of Professor D. J. Birch upon Myers [1997] Crim LR 888 at 891.

40 The concept has been mentioned elsewhere, e.g. in R v Momo [2001] EWCA Crim 397, where Kay LJ stated (at [28]), 'there were no grounds for taking the view that it was evidence on which no reasonable jury could rely because it was worthless evidence. Only if evidence can truly be said to be worthless, and therefore not relevant because of its lack of worth, can one accused be prevented from establishing a matter about the other accused.'

41 In $R$ v Corelli [2001] EWCA Crim 974, Longmore LJ observed obiter that a co-defendant would not be prevented from reopening the issue of voluntariness before the jury where the confession had been admitted pursuant to R v Myers; the same should logically follow where the confession is admitted pursuant to s. $76 \mathrm{~A}(1)$ following a voire dire. The Criminal Law Revision Committee in its Eleventh Report, above n. 19, observed (at para. 63) that, 'evidence of improper conduct 
a co-defendant would continue to derive protection from the judicial warning that the jury should not equate the confession with the Crown's case against him. Furthermore, in those cases where the trial judge was concerned that the admission of the confession might prejudice the fairness of the co-defendant's trial, he could consider making an order of severance; ${ }^{42}$ this would shield the co-defendant from the risk of prejudice, yet respect the defendant's right to adduce evidence of the confession. ${ }^{43}$ Indeed in those cases where the admission of the confession might endanger the fairness of the co-defendant's trial, the trial judge might then be obliged to make an order of severance in order to guarantee that both defendants received a fair trial.

\section{Adducing a co-defendant's confession as a previous inconsistent statement: still possible?}

Prior to the CJA it was an accepted practice that in a joint trial a defendant could prove a co-defendant's confession against him as a previous inconsistent statement pursuant to s. 4 of the Criminal Procedure Act $1865 .{ }^{44}$ The confession was admitted strictly for the purposes of demonstrating inconsistency, and therefore a potential lack of credibility, in respect of the co-defendant's testimony insofar as it was adverse to the defendant's case. ${ }^{45}$ A ruling by the judge that the confession was inadmissible at the suit of the Crown pursuant to either s. 76(2) or s. 78(1) had no bearing on the extent to which a defendant could adduce the confession as a previous inconsistent statement. ${ }^{46}$ However, if the trial judge was persuaded that there was a risk of the jury mishandling the confession and equating it with the Crown's case against the co-defendant, then in the absence of a discretion to exclude the confession, the judge could sever the indictment and order separate trials. ${ }^{47}$ These developments all occurred before the question began to be canvassed before the courts of whether a defendant could adduce a co-defendant's confession as evidence of the matters stated, but even

by the police is likely to make the jury sympathise with the accused ... if it comes out in evidence before the jury that such improper means have been used, this will go far to destroy the utility of the confession from the point of view of the prosecution, unless there is other convincing evidence rendering it credible'. This observation should apply with equal force where it is a defendant that is seeking to adduce the confession, rather than the Crown.

42 See e.g. Lobban v $R$ [1995] 2 Cr App R 573, and P. Thornton, 'The Prejudiced Defendant: Unfairness Suffered by a Defendant in a Joint Trial' [2003] Crim LR 433. The co-defendant might be liable to suffer prejudice in two senses: first, the prejudice of the jury being unable to disassociate the confession from the Crown's case against him; secondly, the prejudice that the invasion of the co-defendant's protective rights has resulted in the production of evidence that is to the direct exculpatory advantage of the defendant.

43 In which case the confession may be adduced as a 'third-party confession' on a discretionary basis pursuant to s. $114(1)(d)$ of the CJA, or 'safety valve'.

$44 R$ v Rowson [1986] 1 QB 174, Lui Mei-Lin v R [1989] 1 AC 288.

45 Lui Mei-Lin v R [1989] 1 AC 288.

$46 R$ v Rowson [1986] 1 QB 174, Lui Mei-Lin v $R$ [1989] 1 AC 288, R v Corelli [2001] EWCA Crim 974. 47 See e.g. R v O'Boyle (1991) 92 Cr App R 202. 
after this matter had supposedly been resolved by the House of Lords in R v Myers, the practice of adducing a confession as a previous inconsistent statement remained intact. $^{48}$

Following the CJA it is doubtful that a defendant may continue to adduce a codefendant's confession as a previous inconsistent statement pursuant to the practice just described, although curiously no overt discussion of this issue may be found in the Law Commission's report, and there is only the most gnomic of allusions to it in the Explanatory Notes to the CJA. ${ }^{49}$ The source of this doubt lies in the inclusion within the CJA ofs. 119, which provides that where a previous inconsistent statement is proved against a witness by virtue of the Criminal Procedure Act 1865, 'the statement is admissible as evidence of any matter stated of which oral evidence by him would be admissible'.

Section 119 is based upon the Law Commission's impression ${ }^{50}$ that jurors undoubtedly struggled to comprehend what Cross ${ }^{51}$ described as a 'gibberish' direction, that a previous inconsistent statement was evidence going merely to the credit of the witness, and not evidence of the matters stated. Moreover, the Law Commission recommended that the hearsay rule could be relaxed in respect of the previous statements of witnesses, given the opportunity that would exist at trial to cross-examine the witness upon their statement. ${ }^{52}$

If the possibility of adducing a co-defendant's confession as a previous inconsistent statement has survived the enactment of the CJA, this would provide a defendant with two routes through which he could attempt to adduce a co-defendant's confession as evidence of the matters stated, assuming of course that the co-defendant chose to enter the witness box at trial: the s. $76 \mathrm{~A}(1)$ route; and the previous inconsistent statement route. It presumably cannot have been the Law Commission's intention, or the UK government's, that a defendant should have the chance of bypassing the constraints within s. $76 \mathrm{~A}$ by adducing a confession as a previous inconsistent statement. If it were otherwise, the illogical situation could arise whereby a codefendant might successfully argue for a confession to be excluded pursuant to s. $76 \mathrm{~A}(2)$, yet later on in the trial the judge might admit the same confession against him as a previous inconsistent statement. Section 76A was drafted with the explicit intention of regulating the extent to which a defendant may adduce a co-defendant's confession by way of exception to the hearsay rule; it therefore must follow that a co-

48 R v Corelli [2001] EWCA Crim 974.

49 Criminal Justice Act 2003 Explanatory Notes, para. 429.

50 Above n. 5 at para. 10.39 .

51 R. Cross, 'The Evidence Report: Sense or Nonsense-A Very Wicked Animal Defends the 11th Report of the Criminal Law Revision Committee' [1973] Crim LR 329.

52 Above n. 5 at para. 10.11. 
defendant's confession may only be admitted as evidence of the matters stated where it complies with s. 76A. The Law Commission envisaged that s. 119 would enable the jury to decide whether any truth in a witness's evidence lay in what they had said in the witness box, or in what they had said in a previous statement made out of court, or possibly neither. ${ }^{53}$ Where the witness is a co-defendant, however, and the previous inconsistent statement takes the form of a confession, the defendant should logically not be entitled to suggest that the truth lies in the inconsistent confession, if this confession could not be adduced by that defendant in direct support of his defence using s. 76A(1).

\section{Conclusion}

This article has attempted to shed some light on the deficiencies within s. 76A in consequence of the Law Commission's narrow analysis of the thorny issue of whether a defendant in a joint trial may be entitled to adduce a co-defendant's confession as evidence of the matters stated. The Law Commission's recommendations that eventually became s. 76A attracted criticism from other writers that the proposals were 'misconceived'54 and 'should be resisted' ${ }^{55}$ It is regrettable that in a post-Human Rights Act environment, the government has failed to heed these warnings. In $R v$ Beckford, ${ }^{56}$ a decision prior to $\mathrm{R} v$ Myers in which a defendant had attempted to adduce a co-accused's confession, the Court of Appeal made the striking observation that 'the hearsay rule, sound though it is when usually applied, is capable sometimes of obscuring-shielding even-the truth. It may have done so here. ${ }^{57}$ Whilst the truth may no longer be shielded by the hearsay rule in a joint trial, unfortunately its legacy may have been inherited by s. 76A(2).

53 Above n. 5 at paras. 10.94-10.98.

54 Hirst, above n. 2 at 164 .

55 Dennis, above n. 29 at 213.

56 [1991] Crim LR 833.

57 Ibid., per Watkins LJ. 